\title{
O NOVO TITULAR, PROFESSOR ÁLVARO VILLAÇA AZEVEDO, PROFERE SEU DISCURSO DE POSSE
}

Exmo. Sr. Diretor Professor Antonio Junqueira de Azevedo, Exmo. Professor Celso Lafer, Exmos. Srs. Professores, hoje empossados, Luiz Olavo Baptista, Fábio Maria De-Mattia e Professora Odete Medauar, Exmos. Srs. Professores,

Queridos Alunos, Acadêmicos do Largo de São Francisco, Amigos Funcionários,

Minhas Senhoras e Meus Senhores.

Sejam minhas primeiras palavras de agradecimento à minha esposa, a meus filhos e a meus pais, que souberam entender, no percurso de minha carreira docente, especialmente nesta Faculdade do Largo de São Francisco, minhas vigílias de trabalhos e de pesquisas na elaboração de livros e de teses e na preparação de minhas aulas.

Em seguida, agradeço a meus colegas professores, a meus queridos alunos e aos funcionários desta Academia, pelo convívio agradável que me vêm propiciando, até o presente momento.

Agradeço, especialmente, ao Professor Antonio Junqueira de Azevedo, por batalhar pela $58^{\mathrm{a}}$ Cadeira de nosso Departamento Civil, cuja vaga é por mim preenchida.

Agradeço ao Professor Titular Celso Lafer, por sua saudação e pelas palavras generosas com que agraciou a mim, como a meus colegas, nesta solenidade de posse.

Sinto-me hoje, mais do que nunca, obrigado a uma prestação de contas de minha atividade como professor desta Faculdade do Largo de São Francisco.

Minha tese de doutoramento sobre o bem de família, mostrava, em 1972, há mais de vinte anos portanto, a necessidade de existir maior proteção à familia, não por iniciativa de seu então chefe, mas por obra de uma lei, com normas de ordem pública, em que o Estado estivesse presente na defesa da família, não só a 
resguardando por seu imóvel, mas por seus bens móveis, como um mínimo ético, capaz de conferir-lhe o indispensável a uma vida digna ou a uma sobrevivência após os percalços da execução de seu patrimônio. Parte do significado dessa tese vingou, recentemente, na Lei n. 8.009, de 1990, em que se asseguraram, indene do fantasma da penhora, o imóvel de residência e/ou os bens móveis fundamentais, que a guarnecem.

Sim, porque como já dizia, criticando o texto de nosso Código Civil, não se pode só pretender a defesa da célula familiar, pelo bem imóvel, pois poucas são as famílias que dele são proprietárias.

O bem de família móvel legal, que idealizamos, é o que a protege, como a lei atual, no momento da adversidade da execução judicial de todos os bens, em que fica em risco a própria existência da família, que deve continuar como sustentáculo do Estado.

Com a tese de livre-docência sobre o inadimplemento do dever de coabitação, em início de 1976, por este direito-dever da personalidade, defendi a implantação do desquite, sem prova de culpa, por ato unilateral do cônjuge, de resilição ou de denúncia do contrato matrimonial, o que era impossível à época; mas que foi, em parte, adotado pela Lei do Divórcio, pouco mais de um ano dessa defesa, nos $\S \S 1^{\circ}$ e $2^{\circ}$, de seu art. $5^{\circ}$ Hoje, a tendência é de resilição automática por mero pedido de separação ou de divórcio, por qualquer dos cônjuges, independentemente de considerações e culpabilidade, desde que cessada a affectio maritalis et uxoris, tornando-se, assim, insuportável a vida em comum

Com a primeira tese em concurso para Professor Titular, nesta Academia, sobre o tema Do Concubinato ao Casamento de Fato, defendida em 1986, mostrei os efeitos daninhos à família brasileira, causados pela secularização do casamento, em 1890, pelo Decreto n. 181. Sim, porque por ela passou a constituir-se a familia brasileira tão-somente pelo casamento civil, em completo desrespeito ao casamento religioso que, para valer, teve de vestir a roupagem registal daquele, desprestigiando-se, também, o casamento de fato, ou de mera convivência, admitido pelas Ordenações Filipinas, de 1603.

O legislador não pode ter a veleidade de alterar as instituições sociais, que nascem, naturalmente, por obra da própria convivência.

Todas as tradições sobre formas de constituição de família, de aproximadamente quatro mil anos, ruíram com essa novel legislação, que, não 
admitindo o divórcio, forçou entre nós o aumento dos concubinatos com desquitados até o advento da lei do divórcio, que encontrou uma sociedade acostumada à convivência concubinária, não se utilizando praticamente dessa lei.

Em nossa tese, esse concubinato puro, não adulterino e nem incestuoso que, nos grandes centros como São Paulo e Rio de Janeiro, constituem, atualmente, $55 \%$ da família brasileira, conforme estatística levantada pela OABSecional do Rio de Janeiro, nada mais é do que o antigo casamento de fato ou more uxorio.

Por obra do destino, aproximadamente dois anos após a defesa dessa tese, foi a matéria incluída no $\S$ III, do art. 226, de nossa Constituição Federal de 1988, sob o nome de união estável, como forma de constituição da família de fato.

A união estável é, portanto, o ressurgimento da antiga forma do casamento de fato ou de conhuçudos, no dizer de Alexandre Herculano.

Só falta, agora, a regulamentação do instituto da união estável, em Projeto de que participo, em tramitação pela Câmara dos Deputados, não para transformá-la em casamento; mas, para que essa união continue livre, contudo responsável, para que, à guisa de promessas de amor, não existam o engodo e o aproveitamento patrimonial de um convivente com relação ao outro.

Com a defesa de tese, que me levou à São Francisco, sobre Prisão Civil por Divida, defendida em início de 1993, propugnei pela eliminação do texto constitucional das duas odiosas exceções, que admitem a prisão civil por dívida do devedor de alimentos e do depositário infiel.

No caso de débito alimentar, sendo devido entre parentes, já tem a natural proteção da consangüinidade, que, por norma de Direito Natural, inserida nos arts. 396 a 398, do nosso Código Civil, possibilita a cobrança e execução patrimonial entre os consangüíneos próximos. Já o débito contratual de alimentos e derivado de iliceidade, em meu entender, não possibilita atualmente a prisão do devedor.

Muito menos é de se admitir a prisão do depositário infiel, posto que esse contrato de depósito não pode ser especial, quanto aos outros. A concordar-se com essa prisão, deveriam estar sujeitos a ela, também, a título de exemplo, o comodatário e o locatário infiéis; o que seria absurdo.

Mas, com essas exceções abertas, no texto constitucional, mostramse válvulas perigosas ao legislador ordinário, que se vê tentado a utilizar-se desse 
instituto violento da prisão civil por dívida, como quando equipara, à figura do contrato de depósito, o de alienação fiduciária, nos moldes do Decreto-lei n. 911 , de 1969, considerando o alienante como depositário "com todas as responsabilidades e encargos que Ihe incumbem de acordo com a lei civil e penal".

Ora, o alienante, que se utiliza do bem alienado à empresa de financiamento, não pode ser equiparado ao depositário, que deve somente guardar a coisa alheia e não se utilizar dela.

Por outro lado, não pode ser depositário quem está pagando, em prestações, o objeto que tem sob seu uso.

Tenha-se presente, ainda, que para executar sua garantia o fiduciáriocredor é proprietário; para sofrer a perda do bem fiduciado, sem culpa do devedorfiduciante, é este quem sofre referida perda! Aliás, o que é verdadeiro absurdo, pois, sendo o fiduciante-devedor considerado depositário, jamais poderia sofrer essa perda patrimonial, ante o princípio já previsto há quase quatro mil anos no Código de Hamurabi e referendado no sistema obrigacional de nosso Código Civil, segundo o qual a coisa perece para o dono ("res perit domino").

Não há razão, verdadeiramente, para que se admita a prisão civil por dívida, que é um execrável resquício do passado, não se confundindo ela com a prisão, no âmbito penal ou administrativo.

Ressalto, neste ponto, e para finalizar, que não pode existir Escola sem a relação triádica do Professor, do Aluno e do Funcionário.

Nesse meio, realizo-me, comunico-me e me completo.

Daí porque é bom lembrar que, jamais, moveu-me o carreirismo, porque o mais nobre das funções do Professor não é angariar títulos, mas exercer o mister de Educador, abrindo os horizontes daqueles que, levados pelo espírito humanista, vieram à nossa Academia, trazidos pela tradição das Arcadas, para receber formação jurídica adequada ao exercício profissional.

Sempre tive em mira tentar fazer algo de útil, o que, em Direito, resulta de uma tentativa de melhor regulamentar a vida de nossa sociedade.

Se algum crédito de minha atividade está ainda por vir, pelo menos tenho a satisfação de ter tentado agir razoavelmente porque, como ensina Johann Wolfgang Goethe, "há homens que nem sequer se equivocam, porque não se propõem a nada razoável".

Obrigado. 